SciTrek - The Science \& Technology

Museum www.scitrek.org

Atlanta Botanical Gardens www.atlantabotanicalgarden.org

Six Flags Over Georgia www.sixflags.com/atlanta

Foam Factory www.whitewaterpark.com/other

\section{History \& the Arts}

So, you've walked through the neighborhoods, shopped, and grabbed something to eat. It's time to visit some of the many educational sites.

Margaret Mitchell House www.gwtw.org

\title{
Milner and Katznelson Named Program Co-Chairs for APSA 2000
}

APSA is pleased to announce that Helen Milner and Ira Katznelson have been named Program Committee Co-Chairs for the 2000 Annual Meeting in Washington, DC, August 31-September 3.

Helen Milner joined the political science faculty at Columbia University in 1986 . Her most recent books are The Political Economy of Economic Regionalism (1997, coedited with Edward Mansfield) and Interests, Institutions and Information: Domestic Politics and International Relations (1997).

Ira Katznelson joined the faculty at Columbia University as Ruggles Professor of Political Science and History in 1994. He has taught at the University of Chicago and the New School for Social Research. His most recent books are Liberalism's Crooked Circle: Letters to Adam Michnik (1996) and Desolation and Enlightenment: Political Knowledge after the Holocaust, Totalitarianism, and Total War (1999).

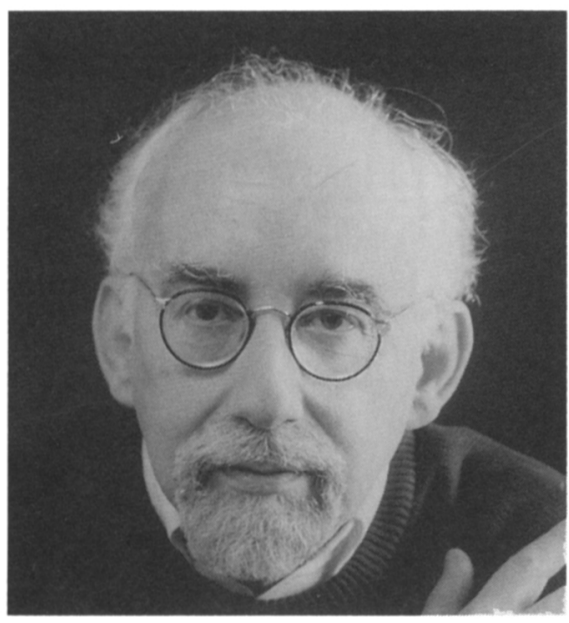

Ira Katznelson
The theme for the $96^{\text {th }}$ Annual Meeting is "Political Science as Discipline? Reconsidering Power, Choice, and the State at Century's End." Power, choice, and the state have been central concepts in political science since its founding as a self-conscious discipline. By reconsidering these orienting themes, the program chairs seek to initiate discussion about both the distinguishing characteristics and internal coherence of political science as well as late-century developments that challenge how the discipline deploys its key organizing concepts.

APSA will begin accepting proposals in September 1999 for panels, papers, and posters related to the organizing theme as well as proposals addressing topics covering the 43 divisions, or subfields, of political science. The September issue of $P S$ and the 1999 Annual Meeting Program will contain submission guidelines and proposal forms.

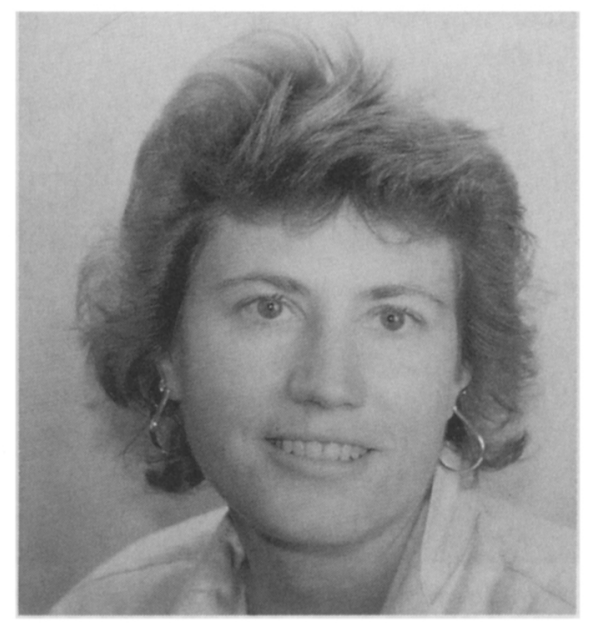

Helen Milner
Fernbank Museum of Natural History www.fernbank.edu

Martin Luther King, Jr. National

Historic Site www.nps.gov/malu

The Carter Center www.CarterCenter.org

High Museum of Art www.high.org

Fox Theatre www.thefoxtheatre.com

\section{Transportation}

Need flight or public transportation information? Visit these web sites. www.itsmarta.com www.atlanta-airport.com

\section{APSA Expands Online Services}

APSA is developing new online resources as it expands its current offerings. APSA's web site (www. apsanet.org) serves as the primary locus of these efforts. In the past year, the Association launched PSonline, PSN Online and the Civic Education Network (CENnet), and the Association plans to introduce a scholar exchange service in early 1999 .

PSonline includes many of the items featured in the print version of PS: Political Science and Politics, including "Washington Insider," scholarly essays and topical articles, and also offers continually updated information on upcoming conferences, grants and fellowships, and related organizations that is no longer published in the print version. The Personnel Service Newsletter (PSN) has made use of Internet technology both in its production and distribution: departments are encouraged to submit listings for PSN through APSA's web site and subscribers can now search the newsletter in its online format.

The Civic Education Network (CENnet) is a resource for civic education teachers at all levels. The site (www.apsanet.org/CENnet) includes scholarly essays and links to civic education resources and organizations. A collection of syllabi and lesson plans and a section on online classrooms are in development. The Association encourages its members 
to submit information for these two sections.

The Association plans to launch the APSA/ECPR Scholar Clearinghouse in 1999. APSA has teamed with the European Consortium for Political Research to produce the clearinghouse, which is designed to facilitate announcement of temporary positions within departments in the United States and Europe. The clearinghouse will feature three types of exchange: departments can post temporary positions; individuals can announce their availability for short term appointments; and departments can work with each other to facilitate a bilateral exchange.

These new projects join the online services that APSA already provides. Our web site continues to be a source of information for the Association's members as well as a convenient way to renew memberships, submit Annual Meeting paper proposals, and preregister for the meeting. APSA's collection of Annual Meeting papers, PROceedings (http://pro.harvard.edu), introduced in 1997 , has become a valuable resource for scholars. More than 550 papers were submitted to the 1998 version and the Association expects the 1999 version to be even larger. In addition to these web-based services, APSA also maintains listservs, including PSRT-L, H-Teachpol, HPolmeth and APSA-CIVED, which facilitate communication among Association members.

Knowing that members will make increasing use of APSA's online services, Council approved the creation of an Ad Hoc Committee on Technology at its most recent meeting. The committee is reviewing APSA's current technological services to determine how to best serve members. The committee welcomes ideas from members and can be reached via email: Pippa Norris, chair, pippa_norris@ harvard.edu; Bill Ball, ball@tcnj.edu; Janet Box-Steffensmeier, jboxstef+@osu.edu; Stephen Weatherford, weather@alishaw. ucsb.edu.

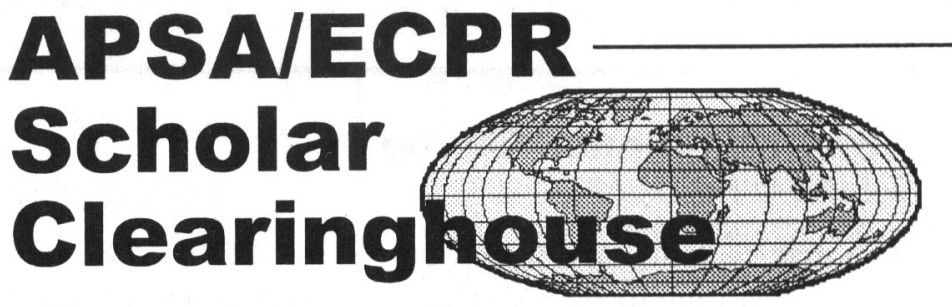

\section{Looking for a new challenge?}

Seeking to promote the exchange of scholars across borders, the American Political Science Association and European Consortium for Political Research have joined together to establish the APSA/ECPR Scholar Clearinghouse.

Designed to facilitate the offering of visiting positions between U.S. institutions and those in ECPR member countries, the program allows colleges and universities the opportunity to strengthen their facultys and departments by presenting a greater variety of course offerings, exposing students to scholars from other countries, and encouraging contact of political science scholars across borders.

The program consists of two primary components: Unilateral exchanges and Bilateral exchanges. Unilateral exchanges consist of individual scholars seeking a visiting position in a department abroad $O R$ departments offering a short-term visiting position to a scholar from abroad. Bilateral exchanges involve one department offering a member of its faculty for a short-term position at another university while hosting a visiting scholar from that university in return.

The process is simple. Scholars with sabattical time or departments with school authorization may advertise positions for free on the site. A brief form is all that needs to be completed. A searchable database helps users find possible matches.

For more information visit APSANet at www.apsanet.org/exchange/ or write exchange@apsanet.org. 